\title{
Canada needs a holistic First Nations health strategy
}

\author{
Alan Katz MBChB MSc, Jennifer Enns PhD, Kathi Avery Kinew MSW PhD
}

Cite as: CMAJ 2017 August 8;189:E1006-7. doi: 10.1503/cmaj.170261

M edia headlines regularly describe the relatively poor health of First Nation peoples in Canada. Among urbanand rural-dwelling First Nations, abysmal living conditions, poor access to appropriate health care services and a marked lack of employment opportunities engender feelings of hopelessness and despair. These challenges have contributed to mental health crises, as exemplified by a tragically high rate of suicide attempts among First Nations youth. Federal and provincial government responses have been shortsighted and have failed to address the real problem. Improving First Nations health and well-being requires a holistic health strategy that draws on the strengths, practices and beliefs of First Nation peoples.

Evidence suggests that suicide and self-inflicted injuries are among the leading causes of death among Indigenous peoples, and that First Nations youth are five to seven times more likely to die by suicide than their non-Indigenous counterparts. ${ }^{1}$ Dramatic spikes in youth suicide attempts occurred in two northern First Nations communities in 2016, prompting renewed analysis of First Nations' health and mental health. Federal Minister of Health Jane Philpott called the suicide crisis among First Nations "one of the most serious and pressing tragedies" facing the country, ${ }^{2}$ and the federal and provincial departments of health responded by deploying mental health crisis workers to some communities to provide short-term support to struggling families and individuals.

Although the federal government committed $\$ 40$ million to build a new hospital in Pimicikamak (Cross Lake) First Nation in Manitoba, where a small, federally funded nursing station has been the only source of primary health services for the 8000 residents, the federal response falls short by failing to address the root of the problem. A new hospital will provide critical health care services to a community that is currently required to airlift expectant mothers, patients needing dialysis and other emergency cases to hospitals in larger urban centres, but it will not even begin to resolve the intractable problem of mental illness, a symptom of the ruthless historical and continuing colonization practices of successive federal and provincial governments in Canada. ${ }^{3,4}$ And it certainly will do nothing to aid other struggling First Nations people living in diverse urban, rural and remote settings across Canada. It is a Band-Aid on a festering wound.

\section{KEY POINTS}

- Large inequities in virtually every measure of health and wellness exist between First Nations and their non-Indigenous counterparts.

- Efforts to improve First Nations' health have been impeded by complex legislative barriers and jurisdictional ambiguities, creating an ineffectual patchwork of policies and practices.

- The historical legacy of colonization and forced assimilation has taken a devastating toll on First Nation peoples in Canada, who face ongoing intergenerational trauma from dispossession of culture, language, lands and ways of life.

- A national First Nations-focused holistic health strategy, led and administered by First Nations according to their right of self-determination, would emphasize cultural respect and safety to remove barriers for First Nations people, and address determinants of health that are relevant to First Nations individuals, families and communities.

A more sustainable solution to the many health challenges faced by First Nations lies in the creation of a First Nationscentred holistic health strategy that goes beyond provision of health services to address the social factors that have precipitated the health crisis. Three components will be critical to such a strategy's success.

First, a successful First Nations health strategy must be grounded in the principles of self-governance and selfdetermination, to ensure equitable resource distribution and organizational cohesion. First Nations-led health care systems and services will increase responsiveness to local needs, improve Indigenous participation in health care and incorporate cultural expression in health care delivery. The government's current approach of perpetual health care pilot projects is not serving First Nations' health care well, because even projects that demonstrate improved outcomes seldom develop into stable, funded programs implemented across jurisdictions. ${ }^{5}$ Not only do the funding agreements for these services fail to address health inequities between First Nations populations and their national counterparts, but they also fail to recognize that the inequities result from historical and existing structures that limit the control First Nations populations can exert over their own affairs. ${ }^{6}$ Current 
government policies and partnerships continue to restrict the sphere over which First Nations can exercise influence, despite making firm commitments to Indigenous self-determination during and after the last federal election. Recognition of First Nations' rights to self-determination underscores First Nations' responsibility in decision-making and control of resources, thereby removing many of the complex legislative barriers currently thwarting progress on improvements to health.

Second, Canadian health care providers must develop and practice cultural respect and safety to remove barriers for First Nations people seeking care, and promote real opportunities for First Nations people in health careers. A fundamental shift in the way health care is provided to First Nations people will require commitment from all levels of government and the institutions that deliver health education to instill a better understanding of health and wellness from First Nations perspectives. Among First Nations, health exists as a balance among the physical, emotional, mental and spiritual elements of life, as expressed by the Anishinaabe term "pimatiziwin": "walking in balance." First Nations share their own understandings of the sacred connection between the Creator and the gifts of Creation. Traditional healing and cleansing practices, including sweat lodges, smudging and other spiritual ceremonies, are fundamental to First Nations' cultural identities and well-being. Best practices for health care involve a spectrum of community services, from traditional medicine by recognized traditional healers to services available from the health care system. ${ }^{7}$

Third, the health strategy should address Indigenous determinants of health. A long history of cultural marginalization, oppression and racism, and socioeconomic factors (including housing, education, income, food security, social environments and access to health care) have been recognized as important determinants that contribute to health inequities between First Nations and non-Indigenous populations. ${ }^{8}$ Cultural continuity, language and self-determination are also critical health determinants that are not typically considered in major health care reform initiatives in Canada, despite growing evidence that they promote resiliency and protect against suicide among First Nations youth. ${ }^{9}$ When First Nations communities were asked what it would take to make their people well, they responded overwhelmingly regarding a need to strengthen their own languages and connections to their lands and waters, which have been under assault by Crown governments, institutions and outside society for many generations. ${ }^{10}$ These complex and intersecting determinants of First Nations health must be considered in any new health initiative.

Generations of policies have contributed to both cultural genocide and First Nations' poor health. The Truth and Reconciliation Committee of Canada's Calls to Action outline the many tasks that remain in our nation's journey toward reconciliation. ${ }^{11}$
Our response must be one determined and led by the original peoples of this land. To begin to fully address the health crisis among Canada's First Nations, we need to recognize First Nation peoples as their own best resource, and prioritize the creation of a national strategy that respects and implements a holistic First Nations-focused approach to health.

\section{References}

1. First Nations and Inuit Health: Suicide prevention. Ottawa: Health Canada; 2006. Available: www.canada.ca/en/health-canada/services/first-nations-inuit-health/ health-promotion/suicide-prevention.html (accessed 2017 July 26).

2. Crisis workers sent to Attawapiskat after spike in suicide attempts. CBC News 2016 Apr. 11. Available: www.cbc.ca/news/politics/attawapiskat-afn-jane-philpott -1.3530042 (accessed 2017 Mar. 23).

3. Allan B, Smylie J. First peoples, second class treatment: the role of racism in the health and well-being of Indigenous peoples in Canada. Toronto: the Wellesley Institute; 2015.

4. Lux MK. Separate beds: a history of Indian hospitals in Canada, 1920s-1980s. Toronto: University of Toronto Press; 2016.

5. Bégin M, Eggertson L, Macdonald N. A country of perpetual pilot projects. CMAJ 2009;180:1185.

6. Lavoie JG. Policy silences: why Canada needs a National First Nations, Inuit and Métis health policy. Int J Circumpolar Health 2013;72:22690.

7. Castleden H, Martin D, Lewis D. From embedded in place to marginalized out and back again: Indigenous peoples' experience of health in Canada. In: Giesbrecht MD, Crooks VA, editors. Place, health and diversity: learning from the Canadian experience. New York: Routledge; 2016:29-53.

8. Loppie Reading C, Wien F. Health inequalities and social determinants of Aboriginal peoples' health. Prince George (BC): National Collaborating Centre for Aboriginal Health; 2009.

9. Hallett D, Chandler MJ, Lalonde CE. Aboriginal language knowledge and youth suicide. Cogn Dev 2007;22:392-9.

10. Avery Kinew K. "Ki nisitotawin na?" ("Do you understand me?"): First Nations in Manitoba setting their own health research priorities. Winnipeg: University of Manitoba; 2014.

11. Honouring the truth, reconciling for the future: Summary of the final report of the Truth and Reconciliation Commission of Canada. Ottawa: The Truth and Reconciliation Commission of Canada; 2015.

Competing interests: None declared.

Affiliations: Departments of Family Medicine (Katz) and Community Health Sciences (Katz, Enns), Manitoba Centre for Health Policy, University of Manitoba; First Nations Health and Social Secretariat of Manitoba (Kinew), Assembly of Manitoba Chiefs, Winnipeg, Man.

Contributors: Based on discussion among all authors, Jennifer Enns drafted the manuscript, and Alan Katz and Kathi Avery Kinew made substantial contributions to shape and revise the final version. All authors reviewed and approved the final version of the manuscript and agree to act as guarantors of the work.

Acknowledgements: The authors appreciate the critical review provided by Wanda Phillips-Beck, Josée G. Lavoie, Grace Kyoon-Achan and Naser Ibrahim.

This article has been peer reviewed.

Correspondence to: Alan Katz, alan_katz@cpe.umanitoba.ca 